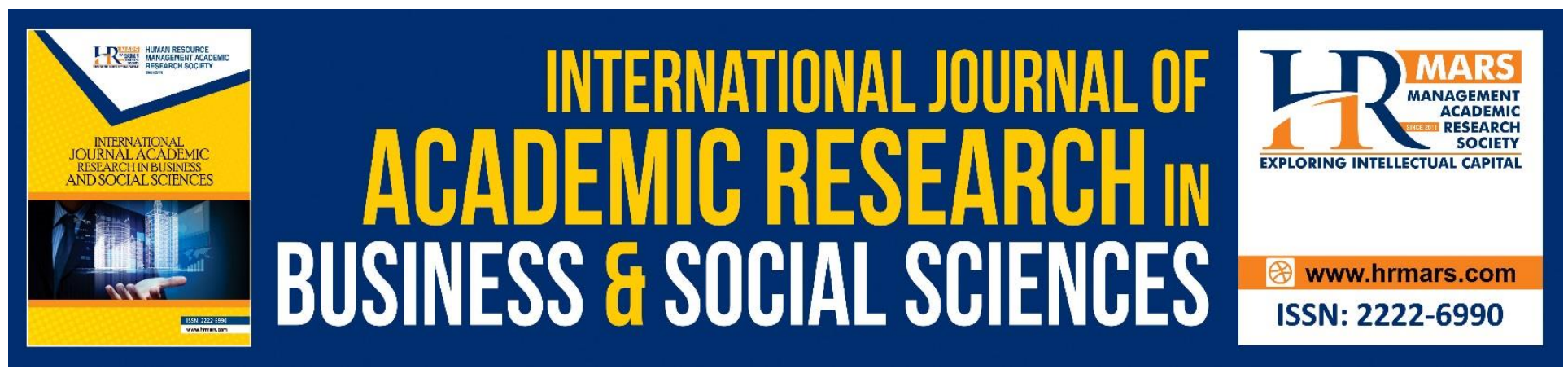

\title{
A Conceptual Framework for Waqf-Based Social Business from the Perspective of Maqasid Al-Shariah
}

\author{
Abd Halim Mohd Noor, Aieshah Abdullah Sani, Zunaidah Ab Hasan, \\ Nor Tasik Misbahrudin
}

To Link this Article: http://dx.doi.org/10.6007/IJARBSS/v8-i8/4635

DOI: $10.6007 /$ IJARBSS/v8-i8/4635

Received: 03 July 2018, Revised: 27 July 2018, Accepted: 29 July 2018

Published Online: 17 August 2018

In-Text Citation: (Noor, Sani, Hasan, \& Misbahrudin, 2018)

To Cite this Article: Noor, A. H. M., Sani, A. A., Hasan, Z. A., \& Misbahrudin, N. T. (2018). A Conceptual Framework for Waqf-Based Social Business from the Perspective of Maqasid Al-Shariah. International Journal of Academic Research in Business and Social Sciences, 8(8), 801-818.

Copyright: (C) 2018 The Author(s)

Published by Human Resource Management Academic Research Society (www.hrmars.com)

This article is published under the Creative Commons Attribution (CC BY 4.0) license. Anyone may reproduce, distribute, translate and create derivative works of this article (for both commercial and non-commercial purposes), subject to full attribution to the original publication and authors. The full terms of this license may be seen

at: http://creativecommons.org/licences/by/4.0/legalcode

Vol. 8, No. 8, August 2018, Pg. 801 - 818

Full Terms \& Conditions of access and use can be found at http://hrmars.com/index.php/pages/detail/publication-ethics 


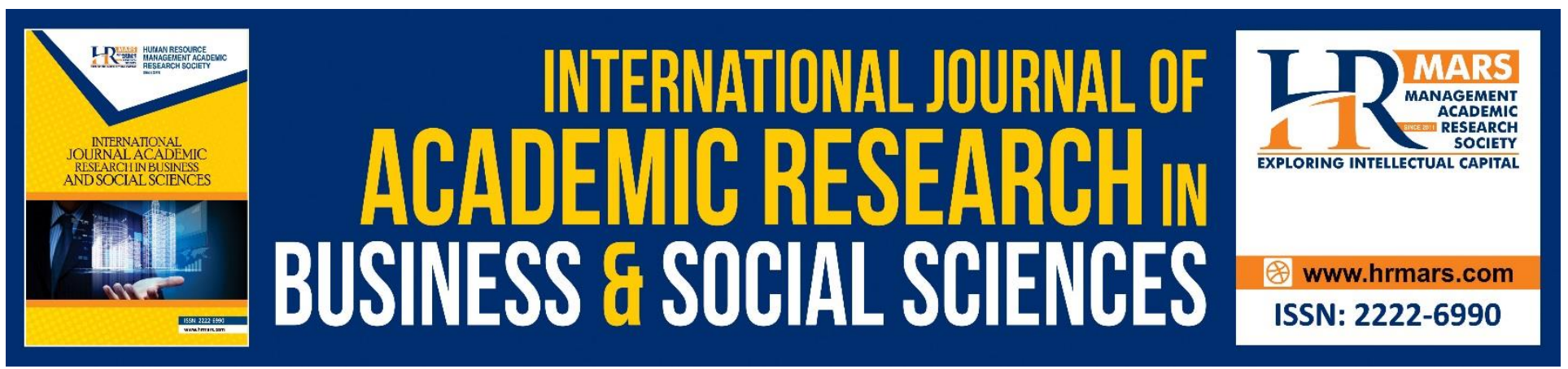

\title{
A Conceptual Framework for Waqf-Based Social Business from the Perspective of Maqasid Al-Shariah
}

\author{
Abd Halim Mohd Noor \\ Universiti Teknologi MARA Melaka, Malaysia \\ Aieshah Abdullah Sani \\ Universiti Teknologi MARA Melaka, Malaysia \\ Zunaidah Ab Hasan \\ Universiti Teknologi MARA Melaka, Malaysia \\ Nor Tasik Misbahrudin \\ Universiti Teknologi MARA Melaka, Malaysia
}

\begin{abstract}
Waqf, a non-profit voluntary sector, have an important and integral role in developing communities during various phases of Islamic communities' development. Recently, voluntary sectors are increasing their presence felt in development of communities. Current reports suggest a surge in the role of voluntary sectors in communities' development. This development also leads to the formation of Social Business (SB) which is hybrid in nature. SB is an entity that incorporates both features of profit sector and non-profit sector. SB model has been presented as a viable model in ensuring organization's longevity. This is evident in the case studies discussed. SB while operates on a business-like conduct, however its main objective is still dedicated for the betterment of society. The trend can also be observed in Islamic based voluntary sectors with the creation waqf-based SB (WSB). Issues regarding sustainability and impact of activities to beneficiaries are of concern to stakeholders. Furthermore, for Islamic based voluntary sector such as WSB, they are bound by Maqasid al-Shariah (MS) or objectives of the shariah. Based on MS index developed for the Islamic banking sector, this paper proposed a conceptual framework that could assist in determining the performance of WSB from the perspective of MS.
\end{abstract}

Keywords: Waqf, Governance model, Maqasid al-Shariah, Social Business, Waqf-based Social Business 
INTERNATIONAL JOURNAL OF ACADEMIC RESEARCH IN BUSINESS AND SOCIAL SCIENCES Vol. 8, No. 8, August 2018, E-ISSN: 2222-6990 @ 2018 HRMARS

\section{Introduction}

In Islam, various instruments namely waqf, zakat and sadaqah are the main tools in creating a benevolent society. Waqf in particular, plays a significant role in ensuring a better living environment and a promising future for its beneficiaries. The word waqf originated from the Arabic language. It can be translated to stop, hold or obstructing. However, in the terms of Islamic law, waqf refers to any property to be held in trust and used for charitable or religious purposes. Waqf institutions, being a non-profit organization (NPO), its dependent on donations limits operator's ability to fully utilize their waqf assets. As such, waqf institutions and other NPOs are turning to business activities to support their mission. This has led to the establishment of SB as it uses economic activity to pursue its social objective. SBs have gained awareness and interest among researchers, yet little is known how these organizations are able to create social and economic value.

Creation of SB evolved from the need of organizations to move beyond the traditional belief that their economic value is separate from and in conflict with their social value. SBs aim to solve social, environmental or societal problems by using modern management practices and means of innovation (Polak \& Warwick, 2013). Compared with traditional non-profit organizations, SBs strive to be profitable. They have developed income generation strategies and are profit-driven.

Non-profit organizations have traditionally operated in the social sector to solve or ameliorate such problems as hunger and homelessness. They have also provided certain basic social goods such as education, they arts and health care. Increasing number of non-profit seeking additional revenues by behaving more like for-profit organizations and some raising funds through auxiliary commercial enterprises. Several non-profits are beginning to commercialize the core programs through which they accomplish their mission; that is, they are looking for ways to make these programs rely less on donations and grants and more on fees and contracts (Dees, 1998).

SB is quite distinct from either traditional profit-maximizing business or a not-for-profit organization (which relies on charitable donations). SB's goal is to solve a social problem by using business methods, including the creation and sale of products and services. SB is quite different from the term "social enterprise" and "social entrepreneurship" as frequently used in the literature. In contrast, SB is a very specific type of business - a non-loss, non-dividend company with social objective. SB may pursue goals similar to those sought by social entrepreneurs, but the specific business structure of SB makes it distinctive and unique (Yunus, 2010). SB challenges many economic and social theories which run against the motivation of SB. SB promotes development of a society with minimal gaps between the poor and the rich. Unlike conventional profit maximizing businesses, SB aims to create opportunities for the less privileged through allowing them to compete in the market based economic activities as equals (Rahman and Hussain, 2012).

Though SBs might be successful in sustaining their parent organizations, the impact to the society at large requires further investigation (Wilson \& Post, 2013). Thus, an assessment framework is therefore necessary to gauge whether waqf-based SBs (WSB) are really providing real and tangible benefit to the community. Although there are accepted accounting principles that supports financial reporting, limitations of financial accounting, which excludes non-monetized items and focuses more on shareholders rather than employees and users at large lacked in providing a complete view on overall performance. Furthermore, similar standards related to measurement and overall impacts are not yet available (Grieco et al, 2014). More pertinently, being an Islamic institution, WSB must also be assessed from the perspective of MS.

Therefore, the objective of this study is to develop a conceptual framework for waqf-based social business from the perspective of MS. This paper is arranged as follows: the immediate section 
INTERNATIONAL JOURNAL OF ACADEMIC RESEARCH IN BUSINESS AND SOCIAL SCIENCES

Vol. 8, No. 8, August 2018, E-ISSN: 2222-6990 @ 2018 HRMARS

presents the overview of social business and waqf-based social business, followed by a section on Maqasid al Shariah and governance model. The paper then proposed a conceptual framework of WSB from the perspective of MS. A conclusion ends the paper.

\section{Overview of Social Business}

\section{Social Business}

A SB is a company that establish mainly to serve social issues in a financially self-sustainable way by the creation and sale of product and services (Yunus \& Weber, 2010). Unlike the traditional business, SB main objective are not to maximize profit even though SB also generate revenue for their sustainability. The SB is said to be successful is based on their impact to the society rather than their profit value. Figure 1 below shows the traditional business model and SB model.

Dimensions of Traditional

Business Model

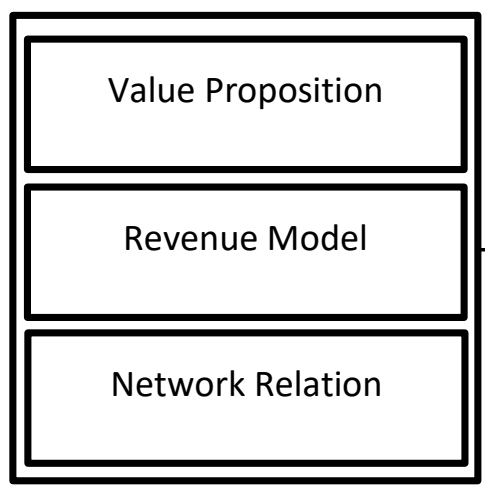

Elements of Social Business

Models

Social Business Impact Model

Community

Engagement Model

Financial

Sustainability Model

Figure 1. Traditional Business and Social Business Model (Ericsson, 2016)

Traditional business model has three dimension namely value proposition, revenue model and network relation. Value proposition is to define what type of product or services to be offer by the business in the market. While revenue model is the way business to gain revenue from the value proposition. This model includes all monetary streams that exists in order to generate revenue for the company. The last dimension is network relation which define as different relation that the company have with their stakeholder and building a network of relations to increase revenue.

In contrast with traditional business, SB identify the social impact proposition at the first place. Social impact proposition is the ultimate reason for the establishment of the SB. In addition, while the traditional business builds their network relation to increase revenue, SB engaged with community which they contribute and trying to aid. Meanwhile the financial sustainability model is design to generate enough profit for their social mission however it is not their main objective. Hence, in order to have a financial sustainability, SB must encompass all elements of traditional business model as shown in Figure 1 above.

Furthermore, it is clearly defined that for-profit and non-profit are two different organization with different mission and goals. However, clear definition of for-profit, mission-driven and SB are currently debatable. They might have similar objectives which are to earn profit either for their stakeholders, investors or for sustainability purposes. However, SB is different from non-profit 
INTERNATIONAL JOURNAL OF ACADEMIC RESEARCH IN BUSINESS AND SOCIAL SCIENCES

Vol. 8, No. 8, August 2018, E-ISSN: 2222-6990 @ 2018 HRMARS

organization or other profit organizations since profit in SB is a tool rather than an end in itself (Ericsson, 2016).

In general, there are four categories of organizations namely non-profit organizations, SB, mission-driven businesses and for-profit businesses. Table 1 below list the differences between various type of organizations in the non-profit and profit-based organization.

Table 1. Types of Business organization

\begin{tabular}{|c|c|c|c|c|}
\hline & $\begin{array}{c}\text { Non-profit } \\
\text { Organization }\end{array}$ & Social Businesses & $\begin{array}{c}\text { Mission-Driven } \\
\text { Businesses }\end{array}$ & $\begin{array}{l}\text { For-profit } \\
\text { Businesses }\end{array}$ \\
\hline Definition & $\begin{array}{l}\text { Organization that } \\
\text { do charity work and } \\
\text { rely completely on } \\
\text { donations and } \\
\text { voluntary work }\end{array}$ & $\begin{array}{l}\text { Businesses that } \\
\text { operates as for- } \\
\text { profit organization } \\
\text { but have social } \\
\text { impact as their } \\
\text { primary intent, } \\
\text { using revenue } \\
\text { streams to } \\
\text { become financially } \\
\text { sustainable in } \\
\text { order to invest in } \\
\text { creating even } \\
\text { more social } \\
\text { impact }\end{array}$ & $\begin{array}{l}\text { For-profit } \\
\text { businesses that } \\
\text { have strong } \\
\text { overarching } \\
\text { missions to } \\
\text { accomplish real } \\
\text { change in society } \\
\text { and exist to make } \\
\text { money for } \\
\text { shareholders }\end{array}$ & $\begin{array}{l}\text { Traditional } \\
\text { businesses that } \\
\text { exist to maximize } \\
\text { profit by } \\
\text { capitalizing on a } \\
\text { certain market or } \\
\text { market niche. }\end{array}$ \\
\hline Example & $\begin{array}{l}\text { 1. Red Cross } \\
\text { 2. Save the } \\
\text { Children } \\
\text { 3. Unicef } \\
\text { 4. Amnesty } \\
\text { International }\end{array}$ & $\begin{array}{l}\text { 1. Grameen Bank } \\
\text { 2. TOMS Shoes } \\
\text { 3. Saiful Nang } \\
\text { 4. Mosque WSB }\end{array}$ & $\begin{array}{l}\text { 1. Tesla } \\
\text { 2. Oatly } \\
\text { 3. Patagonia } \\
\text { 4. Google } \\
\text { 5. LinkedIn }\end{array}$ & $\begin{array}{l}\text { Most for-profit } \\
\text { and stock listed } \\
\text { businesses }\end{array}$ \\
\hline
\end{tabular}

\section{Types and Impacts of Social Business}

According to Yunus \& Weber (2010), SB is a non-loss, non-dividend company mainly for social objectives and can be classified into two types. Type $I$ is owned by investors who later will reinvest all profits to expand and improve the business. The company owner and investor do not earn any personal profit from the business. Meanwhile Type II is business owned by the poor or non-profit institution. The profit that flow to the poor or the institutions are for their sustainability, and to increase their standard of living thus reducing poverty.

An example of Type I SB is TOMS Shoes, a for-profit business with a philanthropic mission. TOMS Shoes entrepreneur Blake Mycoskie witnessed poverty among villagers in Argentina and decided to donate a pair of shoes for every shoes purchase to the Argentinean. He approached all retailer stores in United States to join this social mission. Even though at the beginning only few boutiques in Los Angeles agree to join this mission, after two years the business had \$9.6 million revenue. 
INTERNATIONAL JOURNAL OF ACADEMIC RESEARCH IN BUSINESS AND SOCIAL SCIENCES

Vol. 8, No. 8, August 2018, E-ISSN: 2222-6990 @ 2018 HRMARS

Another Type I SB is the Grameen Group of Bangladesh with a network of nearly 30 sister SBes linked to the Bangladeshi Grameen Bank, the microcredit pioneer (Yunus, Moingeon, \& LehmannOrtega, 2010). Most of the SB created by Grameen Group are well-known and successful because they have entered a joint venture with world-renowned multinational companies. For instance, in 2005 the first joint venture of Grameen with French dairy company, Danone. Danone is a well-known in USA for their Dannon yogurt. The objective of this partnership is to reduce the malnutrition among children in Bangladesh. Grameen Danone produced delicious yogurt which contains all micronutrients with affordable price for the poor. The performance of this company is not measure by the profit gain from the selling of this yogurt, but by the number of children who escape from malnutrition in that particular year.

\section{Waqf-based Social Business}

Waqf (pl. Awqaf) in Islamic law means; holding a certain asset and distribute only the benefits for predetermined philanthropical cause. Waqf play roles in policies of distribution of assets and opportunities. The rewards for person that donating their money and asset for waqf will be remain even after the donors' death, as long as the beneficiaries continue to receive an advantage or benefit from that waqf (Abul Hassan, 2010). Although, waqf had existed before the time of Prophet Muhammad PBUH, waqf had been accepted and built into institution with legal framework in order to fulfil the various need of Muslim communities. This institution has proven in such a long decade in developing the nation by charitable instruments (Hasan \& Abdullah, 2008). Waqf, which is value loaded and value driven Islamic institution, is gaining interest due to the increasing importance of the third (voluntary) sector in the economy. This is partly due to the inability of the rigid two-sector (public-private) to successfully address social economic issues (Arshad \& Hanef, 2015).

Although waqf has mostly existed as a traditional welfare model, currently more waqf bodies has adopted the enterprise-business model in ensuring sustainability of their organizations. Waqf is seen as one of the most suitable instrument to be given as capital or investment for this SB due to its perpetuity characteristic. Perpetuity means the waqf assets cannot be sold, transferred or inherited. Perpetuity means once the assets or property declared as waqf, it will remain as waqf forever (Kahf, 2003). Perpetuity makes waqf a long lasting charity that can maintain the sustainability of the SB.

Waqf benefits can be used in both type of SB. For Type I, waqf institution can set up a business and become the owner or investor for the company. Hence, the profit from the business are 100 percent use to solve the social issues. Waqf institution can take back their original investment amount without any dividend or profit earn. While for the Type II, the benefits or proceeds from waqf assets can be given to the poor and needy as a capital to start a new business or expand their current business. They gain profit from the business for them to increase their living standard. This concept also can be implemented in the non-profit organization.

An example of Type I SB is Malaysia's Awqaf Holdings Berhad that was established in 2012 as a company limited by guarantee. Its main activity is to manage waqf property and other charitable activities. Awqaf Holdings also is a corporate waqf entity. One of its vision to breach economic divides through corporate waqf's, unique capability and harnessing waqf sustainability. Currently, Awqaf Holdings have 751 contributors or waqfers with total contributions of RM4.8 million. Among the beneficiaries are ZuriatCARE program which focuses on creating awareness on the phenomenon of abandoned babies. Other programs such as EduCARE that are design to assist students who are in need of assistance. Public awareness program on waqf are also conducted among the public which include institute of higher education (Awqaf publication, website). 
INTERNATIONAL JOURNAL OF ACADEMIC RESEARCH IN BUSINESS AND SOCIAL SCIENCES

Vol. 8, No. 8, August 2018, E-ISSN: 2222-6990 @ 2018 HRMARS

Another example of Type I SB is Saiful Nang a Malaysia-based philanthropist with various SB companies such as Colours of Asia Sdn Bhd and its subsidiary Social Media Warfare Consultancy, Clothing \& Apparel, Event Management, Online Retails, Professional Large Format Photographic Printing, Training Centre, Petronas Petrol Pump station, Transport \& Logistic, Used Car, Online Security System and Importer of Electronic Goods. All profit from these companies are channelled for SB. Furthermore, employees of these companies are the poor and needy. Hence, Saiful Nang SB also assist in solving poverty through providing job opportunities. In addition, Saiful Nang Academy is a platform for the Asnaf to gain various knowledge and developing new skills both spiritually and physically. Besides that, the Asnaf also was given training for their skills improvement.

In Malaysia, the most common are Type II SB. State Islamic Religious Councils (SIRCs) are the trustee for all waqf assets. Besides the traditional approach of developing waqf assets, SIRCs also have diversified their method on helping the society through waqf fund. SIRCs and their subsidiary have developed several projects such as hotels, hospitals, clinics, schools, universities and high impact small projects. Hence, the benefits from these projects can be invest to the business for social purpose.

Similarly, another Type II SB is a SB run by mosques in Malaysia. Omar, Hussin, \& Muhammad (2017) have examine the status and achievements of SB through the economic activities of the mosques in Perak and Negeri Sembilan. These mosques run the Type II SB as all profits from the business are reinvest for the sustainability of the mosque. Mosque has many physical and nonphysical resources such as cash waqf, land, hall, conference room and shop lots. All of these resources can be utilized to run business and generate income. From the study, it was found that the mosque institution has implemented basic SB activities including rental of mosque assets, undertake agricultural projects and invest in mosque cooperatives. Therefore, mosques are able to earn a monthly income from those activities between RM2, 000 to RM10, 000. Thus, SB activities can help the management of the mosque to generate their own income and expand the economic growth rather than fully depends on the donation from public. 
INTERNATIONAL JOURNAL OF ACADEMIC RESEARCH IN BUSINESS AND SOCIAL SCIENCES Vol. 8, No. 8, August 2018, E-ISSN: 2222-6990 @ 2018 HRMARS

Table 2. Type I and Type II WSB in Malaysia: Example, Activities and Impact

\begin{tabular}{|c|c|c|}
\hline & Type I & Type II \\
\hline WSB & Awqaf Holdings Berhad & State Islamic Religious Councils \\
\hline Activities & $\begin{array}{l}\text { Corporate waqf, manage waqf } \\
\text { property and other charitable } \\
\text { activities } \\
\text { have } 751 \text { contributors }\end{array}$ & $\begin{array}{l}\text { Developed waqf assets and waqf } \\
\text { fund } \\
\text { Example of waqf projects are } \\
\text { hotels, hospitals, clinics, schools, } \\
\text { universities and high impact } \\
\text { small projects. }\end{array}$ \\
\hline Impact/Beneficiaries & $\begin{array}{l}\text { ZuriatCARE program } \\
\text { EduCARE } \\
\text { Waqf awareness program }\end{array}$ & $\begin{array}{l}\text { Benefits invested for social } \\
\text { purpose. }\end{array}$ \\
\hline WSB & Saiful Nang Group & Mosque WSB \\
\hline Activities & Create several SB companies & $\begin{array}{l}\text { Profits used for mosque } \\
\text { sustainability Mosque } \\
\text { implemented basic SB activities } \\
\text { including rental of mosque } \\
\text { assets, undertake agricultural } \\
\text { projects and invest in mosque } \\
\text { cooperatives. }\end{array}$ \\
\hline Impact/Beneficiaries & $\begin{array}{l}\text { All profit are channeled for SB. } \\
\text { Provide job opportunities for poor } \\
\text { and needy. } \\
\text { Platform for the poor to gain } \\
\text { knowledge and developing new } \\
\text { skills both spiritually and physically. }\end{array}$ & $\begin{array}{l}\text { Mosques become financially } \\
\text { independent and less dependent } \\
\text { on the public donation. }\end{array}$ \\
\hline
\end{tabular}

WSB being an Islamic institution, its performance is measured by Islamic based framework namely the MS. The MS contains five main elements namely faith, intellect, life, progeny and wealth. The following section discusses MS.

\section{Maqasid al-Shariah}

Maqasid al-Shariah literally defined as the objectives of Islamic law that covers all aspects in life to enhance the human wellbeing in social, economic, personal, intellectual and political matter. MS also reflects the holistic view of Islam, which is a complete and integrated code of life encompassing all aspects of life either for individual or social in this world and the Hereafter (Abdullah and Dusuki, 2007). The basic framework of MS can be classified into three main elements which are education, justice and public welfare (or known as maslahah) whereby these elements facilitate the improvement and perfection of human life in this world (Mohamed \& Dzuljastri, 2008). As reported by Al-Ghazali (1937) page 139-140: "The very objective of the Sharīah is to promote the well-being of the people, which lies in safeguarding their faith (dīn), their self (nafs), their intellect ('aql), their posterity (nasl), and their wealth (māl). Whatever ensures the safeguard of these five serves public interest and is desirable, and whatever hurts them is against public interest and its removal is 
INTERNATIONAL JOURNAL OF ACADEMIC RESEARCH IN BUSINESS AND SOCIAL SCIENCES

Vol. 8, No. 8, August 2018, E-ISSN: 2222-6990 @ 2018 HRMARS

desirable." These five wordly purposes play a significant role not only for short term but more important in long term for continuous and survival benefit in this world and Hereafter.

Additionally, the broader perspective of MS has been mentioned by Bedoui (2012) and implemented by (Asutay and Harningtyas, 2015) in their research paper on developing the MS index in evaluating social performance in Islamic financial institutions highlighted that the concept of MS must be balanced and equally weighted within the four objectives and eight outcomes based on Abdel Majid Najjar as shown in the table below:

Table 3. Najjar's Concept of MS

\begin{tabular}{|l|l|}
\hline $\begin{array}{l}\text { (i) Safeguarding the value of } \\
\text { human life }\end{array}$ & $\begin{array}{l}\text { (a) Faith } \\
\text { (b) Human rights }\end{array}$ \\
\hline $\begin{array}{l}\text { (ii) Safeguarding the human } \\
\text { self }\end{array}$ & $\begin{array}{l}\text { (a) Self } \\
\text { (b) Intellect }\end{array}$ \\
\hline (iii) Safeguarding the society & $\begin{array}{l}\text { (a) Posterity } \\
\text { (b) Social entity }\end{array}$ \\
\hline $\begin{array}{l}\text { (iv) Safeguarding the physical } \\
\text { environment }\end{array}$ & $\begin{array}{l}\text { (a) Wealth environment } \\
\text { (b) Environment (Ecology) }\end{array}$ \\
\hline
\end{tabular}

Source adopted from Asutay and Harningtyas (2012)

Based on Najjar's concept of MS, the outcomes within each objective represent the basic five objectives of Maqasid that originally from Imam Abu Hamid al-Ghazali, a prominent and highly respected scholar in the fifth century of Hijrah, classified maqasid into five major categories which are protecting faith, self, intellect, posterity and wealth.

The objectives in MS has been reflective to suit SB framework since it involves a serious obligation of each individual and organization to establish justice and social welfare. Nowadays, the acceptance of MS receives increasing attention and it is indoctrinated in industries such as Islamic finance and Islamic economics. Therefore, applying MS in SB framework which primarily focuses on the social and community impact is pertinent as it is associated with the shariah underlying principle to promote benefit to the public (maslahah). Based on the concept introduced by Mohammed $\&$ Taib (2015) and Mohammed et al. (2008), the elements of first objective in MS which is protecting faith and religion is being measured based on the SB's philosophy and values as well as the affordable and halal products produced, and services rendered by SB. Thus, the indicators of faith can be conducted through analysis of SB's vision and mission statement and ways of the functional distribution of its products and services.

\section{Governance and MS Perspective}

The concept of governance has been literally defined as "systems and processes that ensure the overall direction, effectiveness, supervision and accountability of an organization" (Cornforth, 2003). The elements of governance mechanisms can include governing boards, monitoring systems, signalling mechanisms like reporting or codes of conduct and ensuring the interests of stakeholders are represented (Low, 2006; Huybrechts, 2010). While the issues of corporate governance have been widely discussed in the business world, there is a research gap on the governance issues in the other sector such as in SB. The basic governance structure applies for profit organization also could be 
INTERNATIONAL JOURNAL OF ACADEMIC RESEARCH IN BUSINESS AND SOCIAL SCIENCES Vol. 8, No. 8, August 2018, E-ISSN: 2222-6990 @ 2018 HRMARS

parallel with the other sectors, yet the specific features of SB including waqf-based structure for instance the social mission, citizen involvement, and stakeholder's goals may bring a specific and crucial challenges to implement it.

The importance of governance as a mechanism to control the use of power with policies and to enhance the prosperity and viability of the organization is acknowledged by both academics and policy-makers today (Web Finance, 2016). In Islamic perspective, governance is seen in the holistic form, unlimited to the religious matter; but also including social and economic life, politics, business and contract law. The practice of Islamic governance should be portrayed individually via high daily code of conduct that emphasis on honesty, fairness, accountable and responsible to increase his productivity in every business transaction (Hafeez, 2013). Further, the concept of MS as a main framework related to human life and wellbeing has great relevance to corporate governance, ethics, fairness, accountability and responsibility in order to establish justice and equality in business, finance and organization. The absence of equality and justice will create hardship for people and thus difficulties for the entities to operate in a sustainable form which at the end deviates the principles of Islamic governance (Salman, 2014).

Generally, the elements of MS in corporate governance should ensure the management of the organization is conducted based on Islamic rules and being accountable for all the activities that benefits the society through prohibition of fraud, bribery and less asymmetric information to the users, while promoting independence and competency of the board in decision making to be more transparent in preserving the rights of the stakeholders and to act ethically responsible and trustworthy (Salman, 2014). For achieving MS, good corporate governance structure, sound ethical practices, and good regulatory framework are needed to ensure that responsibility, accountability and transparency prevails in the organization through educating and creating awareness among the people in reducing asymmetric information, providing fair market place to the players with the sustainability approach and promoting the real transactions that helps and serves the community and the environment (Lahsasna, 2013).

The principle of good governance also has been discovered in the Holy Quran and this concept is well defined in all aspects of life including economic, justice, defence, and public welfare. Based on prior studies, the imperative of good governance has been stressed throughout the Muslim history by almost all scholars including Abu Yūsuf, al-Māwardi Ibn Taymiyyah and Ibn Khaldūn. However, the absence of good governance over the past several centuries has become a major cause of falling Muslim leadership today's in the world (Chapra, 2009). A study conducted by Naqvi et al. (2011) perceives that Islam demonstrates a clear and firm concept of good governance with reference to the Holy Quran. It is mentioned that the approved leader must possess a good governance and responsible for the smooth and effective institution in all necessary disciplines mainly including "Islamic (Allah's) laws and values; a political system for electing or selecting the Islamic leader; an interest free economic system; a system for public welfare; a system for defence; a system for fair and free justice; rule of law and order; a system for transparent planning and delegation of authority; an unbiased system of accountability; a system of education and a system of taxation" (pp. 10989). Consequently, applying maqasid perspective able to create strong check and balance strategy for promoting high values in the good governance structure through reviewing, auditing, risk management and comprehensive guidance to the organization consistent with the values of Shariah. 
INTERNATIONAL JOURNAL OF ACADEMIC RESEARCH IN BUSINESS AND SOCIAL SCIENCES Vol. 8, No. 8, August 2018, E-ISSN: 2222-6990 @ 2018 HRMARS

\section{Governance Models of WSB}

Generally, there are several governance models has been discussed that applied for various entities such as the agency theory (the compliance model), the stewardship theory (a partnership model), the resource dependency theory (a co-optation model), a democratic perspective, a stakeholder perspective and the managerial hegemony theory (a rubber stamp model). The notion that the SB principles is a distinct sector in their own right has been acknowledged as a sub set of the non -profit sector. This is also applies to Islamic voluntary based SB particularly in waqf sector. As suggested from the literatures, the SB sector will exhibit a democratic model of governance based on the stakeholder perspective (Low \& Low, 2006; Huybrechts and Defourney, 2008; Yu, 2013). Literally, stakeholders are defined as "any group or individual who can affect or is affected by the achievement of the organization's objectives" (Freeman, 1984, p.46). The term stakeholders will be used in its broadest sense to refer to "those groups or individuals with whom the organization interacts or has interdependencies" and "any individual or group who can affect or is affected by the actions, decisions, policies, practices or goals of the organization" (Carrol 1993, p.8).

Meanwhile the stakeholder theory draws a conceptual tool to analyse the participation and influence of multiple stakeholders in an organization's governance. This theory accounts for all individuals who are socially impacted or who have a social impact on the firm through social drivers internally and externally as well as barriers to the social responsibility practices (Burga \& Rezania, 2016; Yu, 2013). Accordingly, a number of past research mentioned that the organization using governance model under stakeholder perspectives should be responsible to a range of stakeholders in society other than just the owners or people inside the organization. Organizations will be more likely to respond to broader social interests by incorporating different stakeholders into their boards (Cornforth, 2004; Low, 2006; Huybrechts, 2010). As described by Spear, Cornforth and Aiken (2009), multiple stakeholder participation in board provide various perspectives in making decisions to ensure all the different interests are balanced against each other, though it will make more difficult to achieve a clear purpose and reach the agreements. In recent years, many relevant studies have thrown light on the governance structures of SB from a stakeholder participation perspective (Cornforth, 2004; Low, 2006; Mason, 2009; Spear et al., 2009; Huybrechts, 2010; Yu, 2013). Parallel to the organizational form of SB, the governance structure can involve either a single category of stakeholders (members, users, beneficiaries, employees, or donors) or multiple stakeholder participation at one time. Within the social enterprise context, two general groups are identified as the internal and external stakeholders. External group includes the community, government agencies, donors or private investors while the internal group includes founding members, volunteers, and support staffs in the delivery of the social services (Rynning, 1995 and Martin \& Thompson 2010).

In relation to WSB, it has been witnessed that the stakeholder theory should be applied to enhance the governance structure in these organizations. Alias (2012) stated that the Waqf institutions should be guided by a code of governance and possibly a code of ethics that will help them to understand their role, exercise control over the waqf assets and allow them to discharge accountability. In the case of a non-profit religious organization like waqf SB, a solid governance structure can improve accounting practices and performance toward enhancing accountability (Ramli et al., 2015). However, evidence showing the adoption of an effective code of governance has yet to be found for waqf institutions. Hasan and Siraj (2017) has proposed the modified stakeholder model trust in waqf institutions based on Commitment-trust theory that combined with Islamic accountability and Stewardship theory. Based on this modified model, stakeholder trust is positioned 
as a mediator between independent (board benevolence, board ability, board integrity, board opportunism, communication and accountability) and the dependent variable (stakeholder commitment). The modified model of trust can determine the significance of governance, accountability and disclosure in improving trust toward enhancing stakeholder commitment.

\section{Maqasid al-Shariah Conceptual Framework of WSB}

Among the pioneering studies in utilizing MS as a framework in analyzing of activities of Islamic institutions were undertaken by Asutay \& Harningtyas (2015) and Mohammed \& Razak (2008). Asutey \& Harningtyas developed a performance measurement whether Islamic finance institutions fulfil MS conditions. They developed MS index to measure social performance of Islamic banks. They adopted eight orientation or articulations to construct an evaluation framework aligned with MS. The study conducted empirical investigation on 13 banks from 6 countries for the period 5 years. The findings revealed lack of achievement in MS performance of Islamic Bank and finance. The industry mainly focusses in self, faith and rights stake holding rather than wealth orientation, and only few contributions in social entity, intellect, posterity and ecology (Asutay \& Harningtyas, 2015). Meanwhile, Mohammed \& Razak (2008) analysis the performance of Islamic banks by MS framework, analyzed are using seven performance ratios and the findings show inconsistency on the part of the individual Islamic banks to focus on the overall Shariah objectives. 
Features \& Characteristic

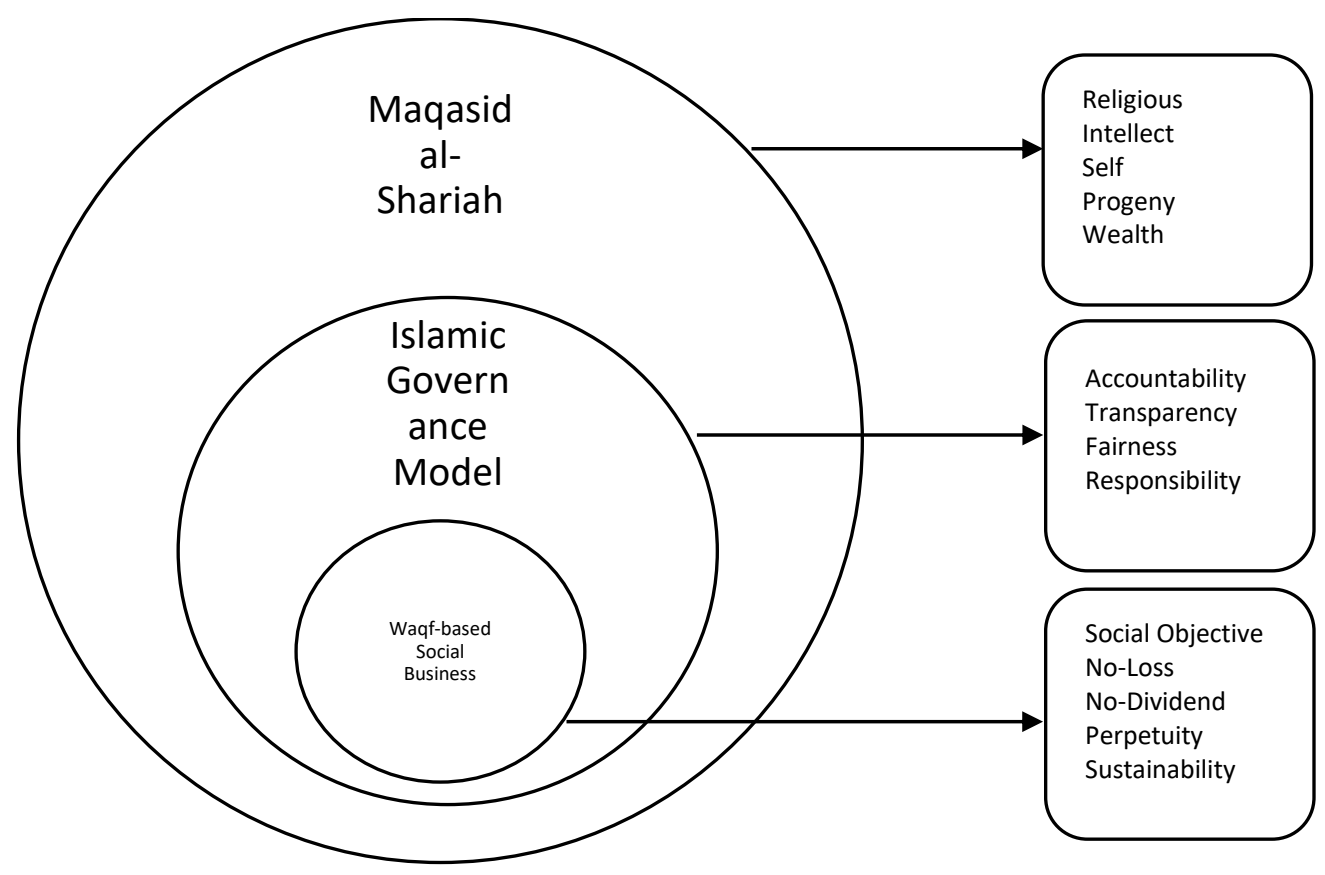

Figure 2. Relationship between Islamic governance, WSB and MS

Assessment must be in line in achieving the five objectives in Shariah. Following Asutay \& Harningtyas (2015) and Mohammed \& Razak (2008), this study introduces MS based framework for WSB. The proposed framework WSB apply five main tenets of MS namely faith, intellect, life, progeny and wealth. Each tenet is detailed through various dimensions, elements and indicators. Dimension are scope for each tenet while elements identify features of dimensions. Finally, indicators operationalize the elements. The operating of WSB should also adhere to Islamic Governance Model (IGM) in terms of fairness, transparency, accountability and responsibility. Figure 2 illustrates the relationship between MS, Islamic governance model and WSB. It highlighted that MS encompassed every aspects of Islamic governance model which in turn embodied the activities of WSB. While Figure 3 below illustrates the propose framework of WSB from the perspective of MS. 
INTERNATIONAL JOURNAL OF ACADEMIC RESEARCH IN BUSINESS AND SOCIAL SCIENCES

Vol. 8, No. 8, August 2018, E-ISSN: 2222-6990 @ 2018 HRMARS

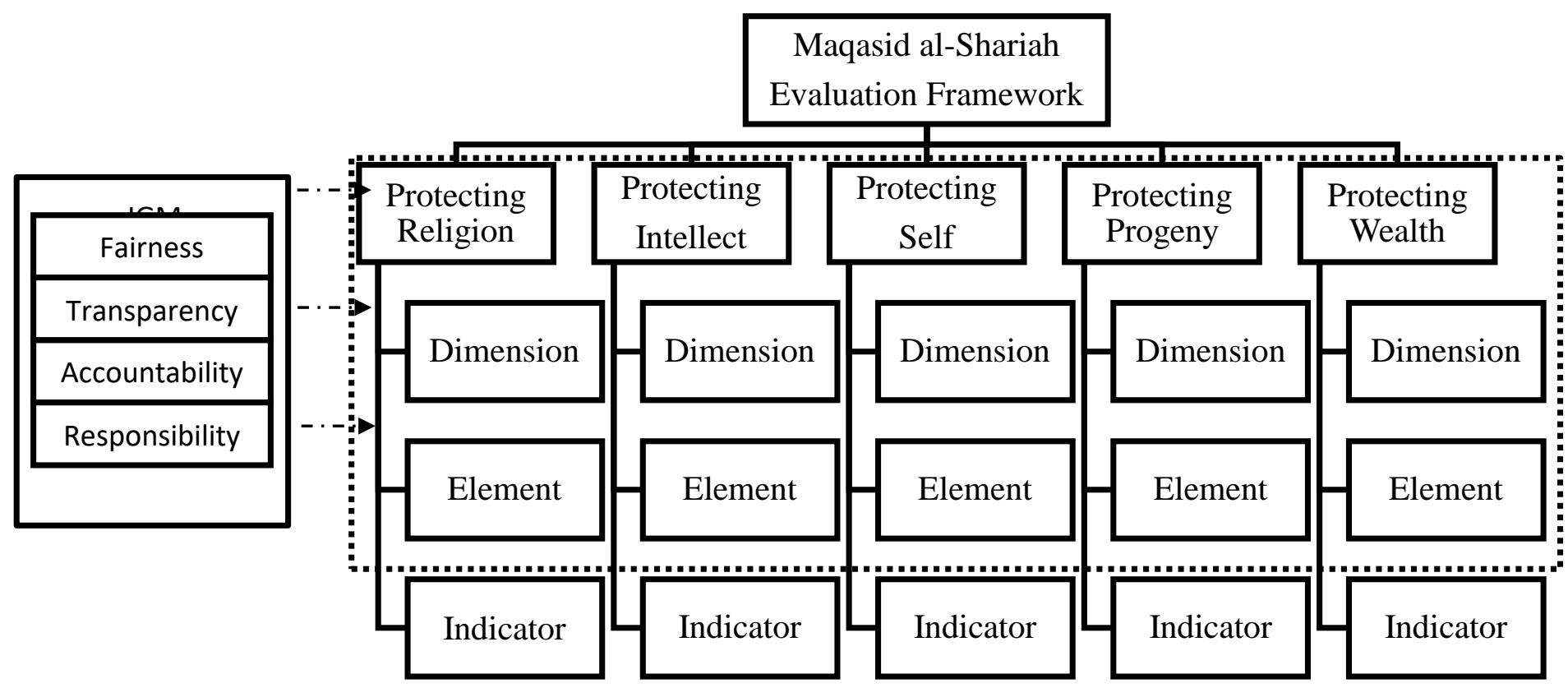

Figure 3. Proposed framework WSB from the perspective of Maqasid al-Shariah (Mehmet \& Astrid, 2015), (Mohammed et al. 2008))

The details of the dimensions, elements and indicators for each tenets as illustrated in Figure 3 is explained in the following. Religion or faith is the first tenet in MS focus on philosophy and values; affordable and halal in activities of WSB. This is translated through vision, mission and functionality of WSB. This will be indicated by operating within Shariah principles or ideals that serve the needs of the Muslim communities, stakeholder and beneficiaries. The second tenet is intellect. WSB is expected to advance knowledge and develop new skills providing grants for research and training. WSB also should create awareness on the importance of intellectual development among the Muslim community. For the life tenet, WSB focus on security, health, freedom and justice of Muslim community in engaging the SB activities. This could be achieved by providing fair allocation for security, health and distribution to the beneficiaries.

The fourth tenet is protecting progeny. The identified dimension of this tenet focus on social development and welfare of stakeholders. This can be evidence through philanthropic sources such as zakat, waqf, benevolent loans and charities to fulfill the needs of social welfare objectives, economic opportunities, training and Shariah awareness. Finally, wealth is the fifth tenet in MS. To ensure wealth is efficiently and productively manage, WSB is expected to apply good corporate governance such as accountability, fairness, transparency and responsibility. This can be reflected through proper code of corporate governance ie existence of audit committee, annual report and board of director committee. Table 4 below illustrate the proposed conceptual framework of WSB. 
INTERNATIONAL JOURNAL OF ACADEMIC RESEARCH IN BUSINESS AND SOCIAL SCIENCES Vol. 8, No. 8, August 2018, E-ISSN: 2222-6990 @ 2018 HRMARS

Table 4. Waqf-based SB from the perspective of Maqasid al-Shariah: A conceptual framework

\begin{tabular}{|c|c|c|c|c|}
\hline No & MS & Dimension & Element & Indicator \\
\hline \multirow[t]{2}{*}{1} & \multirow[t]{2}{*}{$\begin{array}{l}\text { Faith / } \\
\text { Religion }\end{array}$} & $\begin{array}{l}\text { Philosophy and } \\
\text { Values }\end{array}$ & $\begin{array}{l}\text { Vision and Mission } \\
\text { Statement } \\
\text { Disclosure }\end{array}$ & $\begin{array}{l}\text { Operating within Shari'ah } \\
\text { principles/ideals } \\
\text { Providing returns within Shari'ah } \\
\text { principles } \\
\text { Serving the needs of Muslim } \\
\text { community } \\
\text { Commitments to engage only in } \\
\text { permissible activities } \\
\text { Appreciation to stakeholders and } \\
\text { beneficiaries }\end{array}$ \\
\hline & & $\begin{array}{l}\text { Affordable and } \\
\text { Halal }\end{array}$ & $\begin{array}{l}\text { Functional } \\
\text { Distribution } \\
\text { Product \& services } \\
\text { Aspects }\end{array}$ & $\begin{array}{l}\text { No involvement in non-permissible } \\
\text { activities } \\
\text { Basis of Shari'ah concept in approving } \\
\text { product and services } \\
\text { Total revenue Commitments }\end{array}$ \\
\hline \multirow[t]{4}{*}{2} & \multirow[t]{4}{*}{ Intellect } & \multirow[t]{2}{*}{$\begin{array}{l}\text { Advancement of } \\
\text { knowledge }\end{array}$} & Education grant & $\begin{array}{l}\text { Education grant or scholarship/total } \\
\text { expenses }\end{array}$ \\
\hline & & & Research & Research expense/total expenses \\
\hline & & \begin{tabular}{|lr} 
Developing new \\
skills and \\
improvement \\
\end{tabular} & Training & Training expense/total expenses \\
\hline & & Awareness & Publicity & $\begin{array}{l}\text { Publicity expense/total expenses } \\
\text { Channel of publicity and marketing }\end{array}$ \\
\hline \multirow[t]{3}{*}{3} & \multirow[t]{3}{*}{ Life } & Security \& Health & Safety & $\begin{array}{l}\text { Security expenses } \\
\text { Health cost }\end{array}$ \\
\hline & & Freedom \& Justice & Fairness & $\begin{array}{l}\text { Equality of opportunity } \\
\text { Fairness in distribution }\end{array}$ \\
\hline & & $\begin{array}{l}\text { Investment in real } \\
\text { economic sector }\end{array}$ & $\begin{array}{l}\text { Investment ratios } \\
\text { in real economic } \\
\text { sector }\end{array}$ & $\begin{array}{l}\text { Investment in Real Economic } \\
\text { Sector/Total Investment }\end{array}$ \\
\hline \multirow[t]{2}{*}{4} & \multirow[t]{2}{*}{ Progeny } & Social Indicators & $\begin{array}{l}\text { Policy Objectives } \\
\text { and environmental } \\
\text { issues }\end{array}$ & $\begin{array}{l}\text { Mission statement/statement of social } \\
\text { policy } \\
\text { Social target and objective } \\
\text { Consumer Care } \\
\text { Community involvement }\end{array}$ \\
\hline & & $\begin{array}{l}\text { Developmental } \\
\text { and Social }\end{array}$ & $\begin{array}{l}\text { Zakah, waqf, } \\
\text { charity and } \\
\text { benevolent loans }\end{array}$ & $\begin{array}{l}\text { Types, Beneficiaries, Sources and } \\
\text { Amount of waqf } \\
\text { Types, Beneficiaries, Sources and } \\
\text { Amount paid for zakah. } \\
\text { Sources and uses of charity (saddaqa) }\end{array}$ \\
\hline
\end{tabular}


INTERNATIONAL JOURNAL OF ACADEMIC RESEARCH IN BUSINESS AND SOCIAL SCIENCES

Vol. 8, No. 8, August 2018, E-ISSN: 2222-6990 @ 2018 HRMARS

\begin{tabular}{|c|c|c|c|c|}
\hline & & & & $\begin{array}{l}\text { Sources, Policy and uses of qard al- } \\
\text { hassan }\end{array}$ \\
\hline & & $\begin{array}{l}\text { Development and } \\
\text { welfare of } \\
\text { employees }\end{array}$ & Employees & $\begin{array}{l}\text { Employees Expenses/(Total Revenue- } \\
\text { Zakat\&Tax Paid) } \\
\text { Employees appreciation } \\
\text { Number of employees } \\
\text { Equal opportunities policy } \\
\text { Employees welfare } \\
\text { Purpose of Training: Shari'a } \\
\text { awareness, Student/recruitment } \\
\text { scheme, Monetary Reward for } \\
\text { employees \& Other }\end{array}$ \\
\hline 5 & Wealth & $\begin{array}{l}\text { Corporate } \\
\text { Governance } \\
\text { Indicator }\end{array}$ & $\begin{array}{l}\text { Accountability } \\
\text { Transparency } \\
\text { Fairness } \\
\text { Responsibility }\end{array}$ & $\begin{array}{l}\text { There is statement on Corporate } \\
\text { Governance } \\
\text { There is an audit committee and } \\
\text { details of the activities disclosed } \\
\text { There is annual report and is } \\
\text { accessible } \\
\text { Fairness in distribution } \\
\text { Management duties clearly identified } \\
\text { The board of directors comprises at } \\
\text { least one- third of independent non- } \\
\text { executive director } \\
\text { The board of directors has } \\
\text { representative from } \\
\text { background Shariah } \\
\text { The terms of appointment of the non- } \\
\text { executive directors are disclosed } \\
\text { Board meetings were conducted at } \\
\text { least four times a year } \\
\text { Number of board meetings held in a } \\
\text { year and the details of attendance of } \\
\text { each individual director in respect of } \\
\text { meetings held are disclosed } \\
\text { Chairman and CEO are different } \\
\text { persons }\end{array}$ \\
\hline
\end{tabular}

\section{Conclusion}

WSB complement the development of societies and communities. Banking on the donations from charitable public limits the capability of these organizations to effectively perform their function. Recently, increasing number of voluntary and non-profit organization including waqf-based organizations ventured into SB to create a stable fund to finance their operation. In the case of WSB, 
INTERNATIONAL JOURNAL OF ACADEMIC RESEARCH IN BUSINESS AND SOCIAL SCIENCES

Vol. 8, No. 8, August 2018, E-ISSN: 2222-6990 @ 2018 HRMARS

on top of meeting the requirement of operating efficiently and being sustainable it also has to fulfill the MS. MS cover the holistic objective of Muslim in protecting their faith, intellect, life, progeny and wealth. These are essential for ensuring continuity of the ummah and mankind in general.

This study developed a conceptual framework of WSB based on MS. The framework identifies five tenets of MS that WSB must satisfy. Each tenet is further detail through dimensions, elements and indicators. This framework provides specific guideline for WSB in determining whether their activities are in line with the MS. It also serves as self-assessment mechanism for WSB. Adhering to WSB MS framework will develop and enhance public confidence on their organizations which is crucial factors for voluntary organization that depends on public support.

\section{Acknowledgement}

The authors would like to thank to Ministry of Higher Education Malaysia for sponsoring this research through Fundamental Research Grant Scheme (600-RMI/FRGS 5/3 (0047/2016)) and Universiti Teknologi MARA for this research.

\section{Corresponding Author}

Abd Halim Mohd Noor, Center for Islamic Philanthropy and Social Finance, Universiti Teknologi MARA Melaka, Malaysia, Email: drabdhalim@bdrmelaka.uitm.edu.my, rhalimnoor@gmail.com

\section{References}

Abdullah, Nurdianawati Irwani; Dusuki, A. W. D. (2007). MS. Maslahah, and Corporate Social Responsibility. The American Journal of Islamic Social Sciences, 24(1), 25-44. http://doi.org/10.1007/978-3-642-40535-8

Asutay, M., \& Harningtyas, A. F. (2015). Developing Maqasid al- Shari'ah Index to Evaluate Social Performance of Islamic Banks : A Conceptual and Empirical Attempt. International Journal of Islamic Economics and Finance Studies, 1(1), 5-64.

Bedoui, M. Houssem Eddine. (2012). "Ethical Competitive Advantage for Islamic Finance Institutions: How should They Measure Their Performance?" Harvard University.

Burga, R., \& Rezania, D. (2016). Stakeholder theory in social entrepreneurship: a descriptive case study. Journal of Global Entrepreneurship Research, 0-15. http://doi.org/10.1186/s40497-0160049-8

Chiaf, E. (2013). Social Impact Indicators Identification.

Cornforth, C. (2003), "Introduction: the changing context of governance - emerging issues and paradoxes", in Cornforth, C. (Ed.), The Governance of Public and Non-profit Organizations. What do Boards Do? Routledge, New York, NY.

Cornforth, C. (2004), "The governance of cooperatives and mutual associations: a paradox perspective", Annals of Public and Cooperative Economics, Vol. 75 No. 1, pp. 11-32.

Ericsson. (2016). The Social Business Era Creating Impact and Influencing Change.

Hafeez, M. M. (2013). Analysis of Corporate Governance in Islamic and Western. International Journal of Business, Economics and Law, 2(3), 98-103.

Huybrechts, B. and Defourny, J. (2008), "Are fair trade organizations necessarily social enterprises?" Social Enterprise Journal, Vol. 4 No. 3, pp. 186-201

Huybrechts, B. (2010). The governance of fair trade social enterprises in Belgium. Social Enterprise Journal, 6(2), 110-124. http://doi.org/10.1108/17508611011069257 
INTERNATIONAL JOURNAL OF ACADEMIC RESEARCH IN BUSINESS AND SOCIAL SCIENCES

Vol. 8, No. 8, August 2018, E-ISSN: 2222-6990 @ 2018 HRMARS

Imran Haider Naqvi. (2011). The model of good governance in Islam. African Journal of Business Management, 5(27), 10984-10992. http://doi.org/10.5897/AJBM10.1416

Kahf, M. (2003). The Role of Waqf in Improving the Ummah Welfare. In The International Seminar on "Waqf as a Private Legal Body" (pp. 1-26). Medan, Indonesia. Retrieved from http://monzer.kahf.com/papers/english/ROLE_OF_WAQF_IN_THE_WELFARE_OF_THE_UMM AH.pdf

Lahsasna, D. A. (2013). MS in Islamic Finance. Kuala Lumpur: IBFIM.

Low, C. (2006). A framework for the governance of social enterprise. International Journal of Social Economics, 33(5/6), 376-385. http://doi.org/10.1108/03068290610660652

Mohammed, M.O., Abdul Razak, D., and Taib, F.M. (2008). "The Performance Measures of Islamic Banking Based on the Maqasid Framework", Paper of IIUM International Accounting Conference (INTAC IV) held at Putrajaya Marriot Hotel.

Mohammad, M.O. \& Shahwan, S. (2013). The objective of Islamic economics and Islamic banking in light of MS: A critical review. Middle East Journal of Scientific Research, 13, 75-84.

Mohammed, M. O., \& Taib, F. M. (2015). Developing Islamic banking performance measures based on MS framework: Cases of 24 selected banks. Journal of Islamic Monetary Economics and Finance. Retrieved

from http://journalbankindonesia.org/index.php/JIMF/article/view/483/451

Omar, A. R. C., Hussin, M. Y. M., \& Muhammad, F. (2017). Perniagaan Sosial Menerusi Aktiviti Ekonomi Masjid. Journal of Global Business and Social Enterprenuership, 1(1), 39-46.

Salman, S. (2014). Ethics \& governance. The Global University of Islamic Finance, (January).

UnLtd. (2016). Understanding Social Business Models in the Employment Sector Insight for Social Entrepreneurs.

Web Finance (2016). Governance. Retrieved from http://www.businessdictionary.com/definition/governance.html

Yu, X. (2013). The governance of social enterprises in China. Social Enterprise Journal, 9(3), 225-246. http://doi.org/10.1108/SEJ-08-2012-0034

Yunus, M. (2008). Creating a World without Poverty: Social Business and the Future of Capitalism. Global Urban Development, 4(2), 1-19. http://doi.org/10.1080/15575330.2014.890406

Yunus, M. (2015). Yunus Social Business Impact Report.

Yunus, M., Moingeon, B., \& Lehmann-Ortega, L. (2010). Building Social Business Models : Lessons from the Grameen Experience. Long Range Planning, 43(2-3), 308-325. http://doi.org/10.1016/j.Irp.2009.12.005

Yunus, M., \& Weber, K. (2010). Why Social Business. In Building Social Business the New Kind of Capitalism that Serves Humanity's Most Pressing Needs (pp. 1-32). New York: PublicAffairs. 